Interdyscyplinarne Konteksty Pedagogiki Specjalnej
NUMER 21/2018
KORNELIA CZERWIŃSKA
Akademia Pedagogiki Specjalnej im. M. Grzegorzewskiej
w Warszawie
AGNIESZKA PISKORSKA
Uniwersytet Warszawski

\title{
Niewidzenie a kompetencje pragmatyczne w komunikacji
}

\begin{abstract}
Kornelia Czerwińska, Agnieszka Piskorska, Niewidzenie a kompetencje Pragmatyczne $w$ komunikacji [Blindness and pragmatic competence in communication]. Interdyscyplinarne Konteksty Pedagogiki Specjalnej, nr 21, Poznań 2018. Pp. 185-206. Adam Mickiewicz University Press. ISSN 2300-391X. DOI: https://doi.org/10.14746/ ikps.2018.21.10

The paper argues that gaps in knowledge attested in congenitally blind individuals may negatively affect their performance in foreign language tasks testing reading comprehension. Characteristics of a blind learner at various stages of cognitive and educational development are presented, with focus on gaps in knowledge resulting from sight impairment. The concept of pragmatic competence is first explained generally in reference to communication and then it is applied to a case of a comprehension task taken from an EFL exam (Polish "matura", basic level). An analysis of the text indicates that despite being relatively simple in linguistic terms, comprehension tasks may pose a significant processing challenge to blind students due to a large amount of implicitly communicated information dependent on visual experience.
\end{abstract}

KEY WORDS: blind student, EFL, comprehension, gaps in knowledge, pragmatic competence 


\section{Wprowadzenie}

W niniejszym artykule poprzez analizę opisowo-krytyczną źródeł pragniemy zwrócić uwagę na rolę kompetencji pragmatycznych w posługiwaniu się językiem rodzimym lub obcym w celach komunikacyjnych. Kompetencja taka polega na zrozumieniu intencji nadawcy komunikatu, która najczęściej wychodzi poza treść wyrażoną dosłownie i ma ścisły związek z ogólną wiedzą o świecie. Uwzględnienie roli kompetencji pragmatycznej $\mathrm{w}$ komunikacji ma niebagatelne znaczenie w nauczaniu języków obcych osób z niepełnosprawnością wzroku, w tym zwłaszcza osób z wrodzonym niewidzeniem, które w swoim umysłowym obrazie świata mogą przejawiać deficyty wiedzy przyswajanej poprzez bodźce wizualne, co wykazano w wielu pracach ${ }^{1}$.

Uważamy, że zwrócenie uwagi na pragmatyczne aspekty komunikacji werbalnej, a szczególnie na rolę kontekstu $\mathrm{w}$ tym procesię, ma kluczowe znaczenie dla uświadomienia sobie trudności, jakie uczeń czy też każda osoba niewidoma może napotkać w uczeniu się języka obcego. Cechą nauczania języka obcego w warunkach szkolnych jest to, że zawsze proces ten oparty jest na pewnych treściach przekazywanych w tekstach wybranych przez autorów podręczników. Na przykład teksty czytane oraz mówione dotyczą życia szkolnego, sposobów spędzania wolnego czasu, ochrony środowiska, znanych osób itd. Widoczne jest staranie autorów podręczników, aby teksty dotyczyły szerokiego wachlarza tematów, były interesujące, a niejednokrotnie także zabawne, co ma na celu zwiększenie motywacji wewnętrznej ucznia do przyswajania wiedzy z przedmiotu. O ile zawarcie urozmaiconych treści w podręcznikach do nauki języka obcego można traktować jako dodatkową korzyść

${ }^{1}$ B. Marek, A blind child in an English classroom. "Network" 1999, nr 2/1, s. 3-8; A. Marzec, Multiple Intelligences in Second Language Learning: Evidence from Sighted and Totally Blind Students, Rozprawa doktorska, KUL Jana Pawła II, Lublin 2017; J. Sak-Wernicka, The guru effect in blind people's comprehension, [w:] Applications of Relevance Theory: From Discourse to Morphemes, red. A. Piskorska, E. Wałaszewska, Cambridge Scholars Publishing, Newcastle upon Tyne 2017, s. 103-116. 
dla uczniów z niepełnosprawnością wzroku, dla których lekcje mogą stać się okazją do uzupełnienia luk w wiedzy o świecie, o tyle - co pragniemy podkreślić $\mathrm{w}$ artykule - poleganie na wiedzy o świecie związanej $\mathrm{z}$ informacją wizualną $\mathrm{w}$ testach badających zrozumienie języka może niekorzystnie wpłynąć na wyniki osiągane przez osoby niewidome. Jak wykażemy $\mathrm{w}$ omawianym przykładzie, problem ten dotyczy głównie sytuacji, gdy na podstawie informacji wizualnej należy wyprowadzić odpowiednie wnioski dotyczące implicytnej warstwy tekstu, czyli znaczenia niewyrażonego wprost.

\section{Specyfika następstw niewidzenia w obszarze komunikacji}

Dominująca rola, jaką wzrok odgrywa w poznawaniu rzeczywistości materialno-przyrodniczej oraz społeczno-kulturowej, sprawia, że wrodzone uszkodzenie tego zmysłu znacznie utrudnia lub ogranicza szybką i efektywną realizację wielu zadań, zwłaszcza w takich sferach, jak: pozyskiwanie informacji na drodze obserwacji oraz za pośrednictwem materiałów pisemnych i graficznych, orientacja przestrzenna i samodzielne poruszanie się, wykonywanie czynności życia codziennego. Wpływ niepełnosprawności wzroku na poszczególne dziedziny rozwoju oraz sfery psychospołecznego funkcjonowania danej osoby pozostaje zależny od szeregu czynników osobowych i środowiskowych, a wielość i złożoność ich oddziaływań implikuje wysoką heterogeniczność możliwości i potrzeb edukacyjno-rozwojowych $\mathrm{w}$ tej populacji. Obszarem, w którym negatywne następstwa tej dysfunkcji są wyraźnie widoczne, a zarazem szczególnie istotne dla procesu uczenia się osoby, jest szeroko rozumiana komunikacja ${ }^{2}$.

W analizach dotyczących trudności doświadczanych w zakresie komunikacji przez osoby niewidome od urodzenia uwzględniane są przede wszystkim takie jej aspekty, jak: sensoryczny odbiór infor-

2 R. Walthes, Einführung in die Blinden- und Sehbehindertenpädagogik, Reinhardt Verlag, München 2005, s. 52. 
macji na temat przedmiotów, obiektów, osób, zjawisk jako podstawa nabywania pojęć naturalnych, niewerbalne komunikaty i ich rola w rozumieniu pełnego kontekstu określonej sytuacji, wykorzystywanie materiałów pisemnych, graficznych i filmowych w nauczaniu-uczeniu się?

Niemożność wzrokowego pozyskiwania danych o fizycznym i społecznym otoczeniu utrudnia budowanie w umyśle reprezentatywnych modeli rzeczywistości. Kształtowanie pojęć naturalnych odbywa się poprzez doświadczenie zdobywane w bezpośrednim kontakcie z przedmiotami i obserwację zjawisk, czynności i procesów w różnych kontekstach. Konstruowanie myślowego odzwierciedlenia istotnych cech przedmiotu czy zjawiska wymaga więc zgromadzenia odpowiedniej bazy sensorycznej, co w przypadku niewidzenia implikuje konieczność wypracowania skutecznych strategii kompensacyjnych, opierających się przede wszystkim na dotyku i słuchu4. Bezwzrokowe poznawanie obiektów odbywa się w wolnym tempie, wymaga zaangażowania znacznych zasobów uwagowych i pamięciowych, ma charakter fragmentaryczny i zazwyczaj powstałe w oparciu o nie wyobrażenia są uboższe o pewne detale, a więc w pewnym stopniu uproszczone. Należy podkreślić, że deficyty w zasobach pojęciowych obserwowane są u uczniów niewidomych nie tylko w odniesieniu do obiektów i zjawisk niedostępnych obserwacji dotykowej ze względu na stricte wizualny charakter,

${ }^{3} \mathrm{Z}$ uwagi na przyjęty cel niniejszego artykułu oraz ograniczenia objętości nie dokonano w tekście szczegółowej analizy funkcji, uwarunkowań i możliwości stosowania $\mathrm{w}$ procesie nauczania środków tyfloglottodydaktycznych $\mathrm{w}$ formatach pisemnych, graficznych i filmowych. Należy jednak zaznaczyć, iż o ile rekomendacje dotyczące standardów opracowywania i (lub) adaptowania tego typu materiałów są już dość szeroko opisane w opracowaniach krajowych i zagranicznych, o tyle nadal ich dostępność dla osób z niepełnosprawnością wzroku w różnym wieku jest w Polsce niewystarczająca.

${ }^{4}$ K. Jaworska-Biskup, Dlaczego warto uczyć dzieci niewidome języków obcych? Jezyk obcy jako kompensacyjne narzędzie $w$ procesie poznawania świata $i$ zdobywania wiedzy na temat pojęć, [w:] Wyzwania wspótczesnej pedagogiki specjalnej - praktyka edukacyjna i rewalidacyjna, red. T. Żółkowska, B. Ostapiuk, M. Wlazło, Wydawnictwo Uniwersytetu Szczecińskiego, Szczecin 2010, s. 159. 
wielkość, oddalenie czy konsystencję, lecz także uwidaczniają się w przypadku pojęć posiadających materialne desygnaty dostępne w bezpośrednim pokazie ${ }^{5}$. Braki danych sensorycznych, niezbyt precyzyjne doznania zmysłowe, niemożność ujęcia niektórych istotnych związków między elementami otoczenia - o ile nie będą odpowiednio kompensowane $\mathrm{w}$ trakcie wychowania rehabilitacyjnego i edukacji szkolnej - mogą prowadzić do luk w wiedzy ogólnej i (lub) dysponowania nieprawdziwymi informacjami, co z kolei zaburzać będzie konstruowanie w procesie uczenia się nowych modeli i umysłowych reprezentacji rzeczywistości.

Na luki w wiedzy rzutujące negatywnie na efektywność procesu kształcenia uczniów niewidomych, w tym nabywanie kompetencji językowych w systemie rodzimym i obcym, wskazują zarówno doniesienia z praktyki szkolnej, jak i wyniki badań naukowych. Badania ankietowe przeprowadzone wśród 190 tyflopedagogów zatrudnionych w ośrodkach szkolno-wychowawczych specjalizujących się w edukacji dzieci i młodzieży z niepełnosprawnością wzroku wyłoniły jako główne trudności obserwowane u uczniów m.in.: brak lub zaburzenia wyobrażeń o otaczającym świecie, w tym zwłaszcza na temat roślin, zwierząt, przedmiotów, niski poziom wiedzy ogólnej, trudności w myśleniu przyczynowo-skutkowym i abstrakcyjnym, niski poziom wyobraźni przestrzennej itp. Obserwując problemy uczniów w nabywaniu i poprawnym, pełnym rozumieniu wiadomości o bliskim i dalszym otoczeniu, jak również nieumiejętność ich zastosowania w sposób adekwatny do danego kontekstu sytuacyjnego, nauczyciele podkreślali konieczność wdrożenia nowych metod i technik ukierunkowanych na korygowanie deficytów pojęciowych ${ }^{6}$.

${ }^{5}$ E. Więckowska, Edukacja nie wystarczy - potrzeby rewalidacyjne dziecka niewidomego w wieku szkolnym, [w:] Uwarunkowania i kierunki rozwoju pedagogiki specjalnej, red. B. Antoszewska, Cz. Kosakowski, Wydawnictwo Adam Marszałek, Torun 2011, s. 124.

${ }^{6}$ Świat w zasięgu ręki. Dobre praktyki w edukacji uczniów z dysfunkcją wzroku - projekt „Bliżej świata - od konkretu do abstrakcji, red. J. Dłuska, M. Karwowska, W. Karasińska, SOSW nr 1 dla Dzieci i Młodzieży Słabo Widzącej i Niewidomej, Bydgoszcz, 2011, s. 11-13. 
Analizy indywidualnych przypadków funkcjonowania uczniów niewidomych na lekcjach języka angielskiego ujawniły problemy $\mathrm{w}$ posługiwaniu się pojęciami wymagającymi zrozumienia specyficznych cech percepcji wzrokowej, znajomości wizualnych właściwości przedmiotów i zjawisk (np. barwa, przeźroczystość, połysk), operowania relacjami przestrzennymi, jak również posiadania wiedzy o przyjętych zwyczajowo sposobach zachowania się w określonych sytuacjach np. podczas wizyty u lekarza7. Odnotowano luki w wiedzy wynikające $\mathrm{z}$ braku możliwości wzrokowej obserwacji zmian zachodzących w ciele ludzkim w związku z procesami wzrostu, dojrzewania, starzenia się, a także niemożności rejestracji czynności realizowanych w sposób dynamiczny. W uogólnianiu danych pochodzących z opisów przypadków należy zachować pewną ostrożność, gdyż poziom wiedzy ucznia niewidomego we wskazanych obszarach zależny jest przede wszystkim od jego dotychczasowych doświadczeń, w tym okazji do bezpośredniego eksplorowania, aktywnego badania i działania w przestrzeni we współdziałaniu z osobą widzącą (rodzicem, rodzeństwem, nauczycielem, wychowawcą, opiekunem, kolegą), która poprzez dodatkowy komentarz słowny może ułatwić prawidłowe zrozumienie sytuacji, jak również dostarczyć informacji całkowicie niedostępnych w samorzutnym poznawaniu z uwagi na charakter posiadanej przez dziecko dysfunkcji, np. poinformować, czy dane zjawisko ma w ogóle kolor.

W pewnym zakresie nauczycielskie obserwacje prowadzone $\mathrm{w}$ warunkach szkolnych korespondują z wynikami badań przeprowadzonych w grupie 25 niewidomych uczniów w wieku 7-12 lat uczęszczających do szkół specjalnych, które dowiodły, że uszkodzenie wzroku może być z powodzeniem kompensowane przez pozostałe zmysły w zakresie poznawania zjawisk w zastanej rzeczywistości, ale tylko wówczas, gdy zakres i rodzaj dostarczanej stymulacji jest optymalny, dostosowany do indywidualnych po-

7 A. Piskorska, T. Krzeszowski, B. Marek, Uczeń z dysfunkcją wzroku na lekcji angielskiego. Wskazówki metodyczne dla nauczycieli, Uniwersytet Warszawski, Warszawa, 2008, s. 90-92; K. Jaworska-Biskup, Dlaczego warto uczyć dzieci niewidome..., s. 160-161. 
trzeb dziecka. Niewystarczająca lub nieodpowiednia liczba bodźców prowadziła u badanych do egocentryzmu, luk w wiedzy lub niepoprawnego rozumienia pojęć. Wiadomości u niektórych uczniów były tak niewielkie, że nie potrafili oni podać żadnej odpowiedzi. U młodszych uczniów widoczna była preferencja egocentryzmu w języku - podawane skojarzenia dotyczyły przedmiotów $\mathrm{z}$ kręgu ich zainteresowań, dobrze znanych $\mathrm{z}$ codziennych doświadczeń, jak również często powtarzanych, standardowych czynności. $W$ przypadku barw badani bezpośrednio nawiązywali do osobistych przedmiotów, nie występowała u nich zaobserwowana w grupie kontrolnej zdolność do wyszczególnienia detali tych pojęć, umiejętność dokładniejszego określenia i podawania mniej typowych przykładów. Często pojawiały się również pytania o barwy przedmiotów i zjawisk, które nie mają takiej cechy. Warto podkreślić, że zarówno uczniowie widzący, jak i niewidomi ujmowali kolor z perspektywy symbolicznego i emotywnego znaczenia, a leksykon dzieci niewidomych był $\mathrm{w}$ tym zakresie szczególnie bogaty. Ponadto uczniowie niewidomi potrafili określić dane zjawisko i wyszczególnić jego cechy, przy czym przeprowadzona analiza wskazywała na przyswojenie i utrwalenie pojęcia w gotowej formie pochodzącej z przekazu od innych osób. Zauważono także swoistą w przypadku niewidzenia skłonność do myślenia przez analogię̨ Ujawniona $\mathrm{w}$ badaniach silna zależność zasobów pojęciowych uczniów niewidomych w młodszym wieku szkolnym od ich osobistych, codziennych doświadczeń wskazuje na konieczność wykazywania w procesie dydaktyczno-wychowawczym szczególnej wrażliwości na indywidualne różnice $\mathrm{w}$ tej grupie, w tym zwłaszcza uwzględnianie wyjściowej wiedzy uczniów. Istotne jest również zwrócenie uwagi na fakt, że tak ścisłe łączenie danego zjawiska, przedmiotu, cechy wizualnej, wzorca zachowania z określonym, dobrze znanym kontekstem, może utrudniać prawidłowe zrozumienie ich występowania $\mathrm{w}$ odmiennych warunkach sytuacyjnych.

${ }^{8}$ K. Jaworska-Biskup, Wptyw rozumienia pojęć przez dzieci niewidome na nauczanie języków obcych, „Szkoła Specjalna” 2009, nr 1(248), s. 26-31. 
Na przykład założenie czerwonej, obcisłej sukienki na rozmowę kwalifikacyjną o pracę i na uroczystość pogrzebową stanowi w obu tych przypadkach przekroczenie normy zwyczajowej, jednak trafna interpretacja takiego zachowania wymaga szerszej wiedzy na temat symboliki kolorów i jej zastosowania w różnych kontekstach społeczno-kulturowych.

Ryzyko pojawienia się luk $\mathrm{w}$ wiedzy dostrzeżono także $\mathrm{u}$ uczniów niewidomych będących na dalszych etapach ścieżki edukacyjnej. Badania zrealizowane $\mathrm{w}$ grupie 53 uczniów gimnazjum i szkół ponadgimnazjalnych wykazały, że pisemnie przez nich redagowane definicje wybranych obiektów i zjawisk naturalnych o różnym stopniu dostępności (brzoza, łąka, osa, rzeka, tęcza) były bardziej rozbudowane niż w grupie kontrolnej, jednak zawierały też więcej informacji nieprawdziwych, niezgodnych $\mathrm{z}$ wiedzą naukową. Nieadekwatne opisy obiektów wynikały prawdopodobnie z braku bezpośrednich doświadczeń, odpowiedniej reprezentacji w postaci modeli przestrzennych, makiet, rysunków dotykowych, oraz dodatkowo braku możliwości naturalnego utrwalenia zdobytych informacji na drodze swobodnej obserwacji otoczenia w sytuacjach codziennego funkcjonowania9. Zauważyć należy, że niektóre błędy popełnione przez badanych mogą sugerować niewłaściwe zastosowanie analogii $\mathrm{w}$ procesie nauczania-uczenia się. Zdarzało się, że uczniowie przypisywali danemu obiektowi właściwości swoiste tylko dla obiektu, do którego ten pierwszy był porównywany. Można przypuszczać, że w trakcie wskazywania łączących je wspólnych atrybutów nie zostały wyraźnie zaakcentowane występujące między nimi odmienności, które z perspektywy osoby widzącej mogą wydawać się oczywiste; np. porównanie budowy osy do znanej już uczniom pszczoły bez zaznaczenia różnic dotyczących miejsc występowania lub konstrukcji samolotu do budowy ptaka bez określenia odmienności w samej czynności lotu.

${ }^{9}$ N. Mikołajczak-Matyja, Wiedza o obiektach i zjawiskach naturalnych w definicjach konstruowanych przez niewidomych $i$ widzących użytkowników języka, "Szkoła Specjalna" 2006, nr 2, s. 89-103. 
Wskazane powyżej badania potwierdzają słuszność tezy stawianej przez wielu autorów ${ }^{10}$ o uboższym pod względem ilości i jakości zbiorze osobistych doświadczeń uczniów z wrodzoną niepełnosprawnością wzroku rozpoczynających edukację szkolną. Dowodzą także, że podstawowym celem rehabilitacyjnym działań edukacyjnych powinno być korygowanie błędnych wyobrażeń, uzupełnianie luk poznawczych, zapobieganie kształtowaniu nieprawidłowych pojęć. Funkcje kompensacyjne w tym obszarze mogą $\mathrm{z}$ powodzeniem wypełniać zajęcia językowe, w tym z języka obcego, w trakcie których uczniowie niewidomi mają możliwość poszerzania zakresu rozumienia pojęć w różnych kontekstach. Nauka języka obcego wiąże się również z nabywaniem pogłębionej wiedzy o wielu normach społeczno-kulturowych i rozwijaniem zdolności właściwego zachowania $\mathrm{w}$ różnych sytuacjach ${ }^{11}$, co z kolei może skutecznie minimalizować negatywny wpływ niewidzenia w tym aspekcie komunikacji, jaką jest sfera niewerbalna.

Niewerbalne składniki komunikacji są w ograniczonym stopniu percypowane przez osoby niewidome, a brak naturalnych doświadczeń pozyskiwanych na drodze samorzutnej obserwacji i bezpośredniego nawiązywania interakcji międzyludzkich utrudnia zrozumienie funkcji i znaczenia zachowań mimicznych, pozycji i ruchów głowy, gestykulacji, przyjmowanego dystansu fizycznego. Wiedza o specyfice pozajęzykowych zachowań zdobywana przez osoby widzące automatycznie $\mathrm{w}$ toku rozwoju musi być pozyskiwana przez osobę niewidomą w sposób planowy, ukierunkowany, systematyczny, ze znacznym wsparciem udzielanym zarówno $\mathrm{w}$ sytuacjach wychowawczych w środowisku rodzinnym, jak i na zajęciach rehabilitacyjno-edukacyjnych. W procesie wczesnego wspomagania rozwoju dzieci niewidomych zaleca się wprowadzanie

10 Por. B. Papuda-Dolińska, Dziecko z niepetnosprawnością wzroku w roli ucznia szkoły ogólnodostępnej, integracyjnej i specjalnej, Wydawnictwo Uniwersytetu Marii Curie-Skłodowskiej, Lublin 2017, s. 68-78.

${ }_{11}$ A. Olczak, Język obcy w kształceniu zintegrowanym, [w:] Dziedziny ksztatcenia w klasach I-III, red. M. Magda-Adamowicz, L. Kataryńczuk-Mania, Wydawnictwo Akademickie Żak, Warszawa 2013, s. 41-45. 
przez rodziców i opiekunów aktywności zabawowych mających na celu zapoznanie $z$ niektórymi sygnałami pozawerbalnymi stosowanymi zazwyczaj w interakcjach np. ekspresja emocji, gestykulacja, pozycja ciała i ustawienie głowy w trakcie różnego typu kontaktów. Zauważa się jednak ${ }^{12}$, że w przypadku pewnych elementów komunikacji niewerbalnej (np. dystans przestrzenny przyjmowany w kontaktach/sytuacjach o różnym stopniu intymności) niezwykle trudny jest przekaz niezbędnych informacji, gdyż dany obszar interpretowany jest przede wszystkim w oparciu o wskazówki wzrokowe i intuicję. Brak wzroku ogranicza możliwość precyzyjnej oceny relacji przestrzennych w kontaktach społecznych oraz rejestracji zmian zachodzących w bliższym i dalszym otoczeniu, a w związku z tym także dostosowania swojego zachowania do aktualnych wymogów sytuacyjnych. Jak wskazują wyniki badań13, osoby niewidome doświadczają problemów w zrozumieniu pełnego kontekstu sytuacji komunikacyjnej ze względu na niemożność odbioru lub trudność w jednoznacznej interpretacji zachowań i mowy ciała rozmówców.

Kolejną płaszczyznę komunikacji, w odniesieniu do której rozpatrywany jest negatywny wpływ niewidzenia, stanowi przekaz informacji poprzez środki dydaktyczne, które w standardowych wersjach nie są dostosowane do możliwości percepcyjnych osób z tym typem dysfunkcji ${ }^{14}$. W przypadku zajęć językowych ta kwestia wydaje się być szczególnie istotna, gdyż brak odpowiednich tyfloadaptacji znacząco utrudnia równomierny rozwój wszystkich sprawności językowych, w tym zwłaszcza umiejętności czytania

12 J. Konarska, Aktywność komunikacyjna dzieci niewidomych jako warunek ich prawidłowego rozwoju i zapobieganie dystansowi społecznemu, [w:] Dystans społeczny wobec osób z niepetnosprawnościa jako problem pedagogiki specjalnej. Tom I. Przyczyny - Konsekwencje - Przeciwdziałanie, red. M. Parchomiuk, B. Szabała, Wydawnictwo Uniwersytetu Marii Curie-Skłodowskiej, Lublin 2012, s. 188.

13 Por. E. Śmiechowska-Petrovskij, Komunikacja niewerbalna w relacji niewidomywidzacy, [w:] Współczesni ludzie wobec wyzwań i zagrożeń XXI wieku, red. H. Liberska, A. Malina, D. Suwalska-Barancewicz, Difin, Warszawa 2014, s. 267-269.

14 Szerzej na ten temat m.in. w: K. Czerwińska, Pomoce dydaktyczne jako istotny element w edukacji uczniów z dysfunkcją wzroku, "Człowiek - Niepełnosprawność Społeczeństwo" 2013, nr 4(22), s. 173-196. 
i pisania. Postęp technologiczny skutkujący szerokim wyborem rozwiązań informacyjno-komunikacyjnych przeznaczonych dla osób niewidomych i słabowidzących pozwala przełamywać tego typu bariery. Analizując tę kategorię problemów komunikacyjnych, warto jednak zwrócić uwage na dwie dość podstawowe kwestie. Po pierwsze, korzystanie $\mathrm{z}$ wielu pomocy dydaktycznych wymaga wcześniejszego opanowania przez ucznia niewidomego pewnych umiejętności gwarantujących efektywność pracy z danym materiałem, np. systematyczna nauka czytania grafiki dotykowej, opanowanie brajlowskich technik czytania i pisania, zdobycie kompetencji tyfloinformatycznych itp. Po drugie, nierozpoznane u ucznia niewidomego luki poznawcze wynikające z braku odpowiedniej wcześniejszej stymulacji kompensującej niedostatki sensoryczne mogą sprawić, że nowoczesne technologie wspierające proces dydaktyczny okażą się nieskuteczne. Badania wykazały15, że przygotowana zgodnie z przyjętymi standardami audiodeskrypcja do filmu edukacyjnego wykorzystywanego na lekcjach fizyki w liceum była dla uczniów niewidomych niezrozumiała, gdyż nie znali oni opisywanych obiektów, w tym takich jak np. rower - brak doświadczeń w jeździe na rowerze skutkował niską znajomością jego budowy i zasad działania.

Aktualne osiągnięcia tyflopedagogiczne pozwalają zdecydowaną większość wskazanych powyżej utrudnień komunikacyjnych usunąć lub zminimalizować poprzez odpowiednie oddziaływania wychowawcze, rehabilitacyjne i dydaktyczne. Niezbędna jest szczególna wrażliwość nauczycieli na potencjalne luki w wiedzy u uczniów niewidomych wynikające z ograniczeń poznawczych. Brak refleksji pedagogicznej w tym obszarze może skutkować doznawaniem niepowodzeń w realizacji zadań szkolnych, a w szerszej perspektywie doprowadzić do przyjęcia i utrwalenia nieadekwatnych modeli rzeczywistości.

${ }^{15}$ S. Cozendey, M. da Piedade Costa, The audio description as a physics teaching tool, "Journal of Research in Special Educational Needs” 2016, Vol. 16(1), s. 1031-1034. 


\section{Kompetencja pragmatyczna jako warunek skutecznej komunikacji}

Oprócz wspomnianej powyżej wrażliwości nauczycieli na specyfikę poznawczą uczniów z niepełnosprawnością wzroku, istotna jest także świadomość istoty samego procesu komunikacji. Można przypuszczać, iż najbardziej rozpowszechniony w naszej kulturze filologicznej jest kodowy model języka i komunikacji zaproponowany przez Romana Jakobsona ${ }^{16}$. Według założeń tego modelu właściwe zrozumienie komunikatu zależne jest wyłącznie od jego prawidłowego odkodowania, czyli znajomości słownictwa oraz reguł morfo-składniowych. Jedynymi czynnikami mogącymi zakłócić proces komunikacji są przeszkody występujące $\mathrm{w}$ ramach kanału komunikacyjnego, czyli w przypadku osób niewidomych takie utrudnienia, jak brak możliwości odczytania tekstu czarnodrukowego lub zbyt mała ilość czasu na zapoznanie się z tekstem. Jeśli kodowy model komunikacji adekwatnie reprezentowałby procesy zachodzące w ludzkim umyśle w czasie interpretowania wypowiedzeń, to wszelkie egzaminy sprawdzające znajomość języka można by uznać za skutecznie narzędzia badające umiejętności zdającego, gdyż wszystkie osoby, które opanowały język obcy na danym poziomie, miałyby jednakowe szanse i możliwości zastosowania wiedzy i umiejętności językowych do rozwiązania testów ze zrozumienia, a wszelkie różnice wynikające z potrzeby indywidualnych dostosowań byłyby uwzględniane poprzez zastosowanie pisma brajlowskiego i wydłużenie czasu trwania egzaminu.

W ramach badań przeprowadzonych w dziedzinie pragmatyki językoznawczej wykazano jednak już dość dawno, iż odkodowanie komunikatu, czyli zrozumienie znaczenia słów ułożonych w zdanie według reguł składniowych jest jedynie pierwszym krokiem w stro-

${ }^{16}$ R. Jakobson, Poetyka w świetle językoznawstwa, przeł. K. Pomorska, „Pamiętnik Literacki: czasopismo kwartalne poświęcone historii i krytyce literatury polskiej”, 1960, nr 51/2, s. 431-473. http:/ / bazhum.muzhp.pl/ [dostęp: 10.11.2015]. 
nę zrozumienia znaczenia wypowiedzi. Twórca teorii implikatur Paul Grice ${ }^{17}$ zilustrował to zagadnienie takim oto przykładem:

A: Zabrakło mi paliwa.

B: Niedaleko jest stacja benzynowa.

Zauważmy, iż właściwą intencją osoby B nie jest poinformowanie osoby A o tym, co znajduje się w niedalekiej odległości (znaczenie dosłowne zdania), lecz o możliwości kupienia paliwa i rozwiązania problemu. Jest to, według terminologii Grice'a, implikatura wysnuta łącznie z wypowiedzi B oraz wiedzy kontekstowej, w której koniecznie obecna musi być przesłanka mówiąca o tym, że owa stacja jest czynna w chwili rozmowy - inaczej wypowiedź B nie miałaby sensu. Umiejętność odczytania implikatur wymaga więc wyraźnie nie tylko znajomości kodu językowego, ale również zastosowania wiedzy pozajęzykowej do odczytania intencji mówiącego, czyli kompetencji pragmatycznej.

Zmodyfikujmy nieco oryginalny przykład Grice’a, który mógłby brzmieć:

A: Jestem głodny.

B: Niedaleko jest stacja benzynowa.

Zauważmy, iż wypowiedź B będzie mogła być zinterpretowana jako adekwatna do wypowiedzi A tylko przez osobę, która wie, iż na stacji benzynowej można zwykle kupić coś do jedzenia. Jak nietrudno sobie wyobrazić, wiedza taka może być niedostępna osobie, której niepełnosprawność wzroku nie pozwala na samodzielne zorientowanie się, jakie towary oprócz paliwa sprzedawane są na stacjach benzynowych. Zauważmy - co jest kluczowe dla przedstawianej tutaj argumentacji - że to, ile dana osoba niewidoma wie na temat oferty handlowej stacji benzynowych, zależy od jej osobistego doświadczenia - czy towarzyszy kierowcy w kupowaniu paliwa, czy przy tej okazji uczestniczyła w kupowaniu jedzenia na stacji

17 H.P. Grice, Logic and conversation, [w:] Studies in the way of words, red. H.P Grice, Harvard University Press, Cambridge, MA 1975/89, s. 22-40. 
benzynowej itp. Można zaryzykować stwierdzenie, że takie doświadczenie nie jest powszechne. Oczywiście osoba, która nie wiedziała wcześniej, że na stacji benzynowej sprzedaje się jedzenie, nie jest skazana na niezrozumienie wypowiedzi B, gdyż może się tego właśnie domyślić - jest to jej jedyne logiczne uzasadnienie wypowiedzi B jako następstwa A. Zauważmy jednak, że choć takie domyślne założenie może pojawić się w umyśle osoby interpretującej ten dialog, nie jest to jedyna możliwa ścieżka jego zrozumienia. To, jaką drogą podążą myśli odbiorcy, zależeć będzie od wielu czynników, m.in. od dostępności jakiejś innej, alternatywnej interpretacji. Możemy sobie wyobrazić, iż gdyby osoba B znana była z notorycznej skłonności do żartów, jej wypowiedź zostałaby zinterpretowana jako absurdalna propozycja spożycia benzyny. $W$ danej sytuacji taka interpretacja mogłaby być bardziej dostępna i prawdopodobna dla odbiorcy.

Powyższe przykłady miały na celu ogólne zilustrowanie roli kompetencji pragmatycznej w komunikacji, a w szczególności związku pomiędzy możliwością zrozumienia intencji mówiącego a wiedzą o świecie. Jak postulują współczesne teorie pragmatyczne ${ }^{18}$ stawiające sobie na cel pozostawanie $\mathrm{w}$ zgodzie $\mathrm{z}$ badaniami psychologii poznawczej, interpretacja wypowiedzi ma charakter spontaniczny i podporządkowana jest celowi osiągnięcia optymalnych korzyści poznawczych. Innymi słowy odbiorca skonfrontowany z wypowiedzią $w$ danej sytuacji komunikacyjnej nie poddaje jej świadomej analizie, lecz błyskawicznie uzyskuje takie jej zrozumienie, które wydaje się relewantne, tj. wnosi nowe informacje, stanowi odpowiedź na zadane pytanie, modyfikuje wcześniejsze błędne przekonanie, prowadzi do efektu rozbawienia itp.

Jeśli przyjmiemy za wyżej wymienionymi autorami, iż dążenie do osiągnięcia relewantnej interpretacji nadaje kierunek przetwarzaniu komunikatów przez umysł ludzki, stanie się jasne, dlaczego

18 D. Sperber, D. Wilson, Relevance: Communication and Cognition, Blackwell, Oxford, 1986/95; D. Wilson, D. Sperber, Relevance theory, [w:] Handbook of Pragmatics, red. G. Ward, L. Horn, Oxford University Press, Oxford 2016, s. 607-632. 
odbiorcy nieodmiennie odczytują najbardziej dostępne interpretacje jako właściwe i zamierzone przez mówiącego. W nawiązaniu do omówionego powyżej dialogu można zilustrować to następująco: jeśli dla osoby intepretującej wypowiedź B przesłanka mówiąca, iż B ma wielką skłonność do niepoważnych wypowiedzi jest łatwo dostępna, natomiast przesłanka mówiąca, iż na stacjach benzynowych sprzedaje się jedzenie jest słabo dostępna, osoba ta spontanicznie wyciągnie wniosek, iż B żartuje, nie będzie natomiast przeszukiwać zasobów swojej pamięci $\mathrm{w}$ celu utworzenia alternatywnych interpretacji.

Z powyższych rozważań wynika, iż w procesie rozumienia komunikatów niezwykle istotna jest błyskawiczna dostępność takich przesłanek kontekstowych, które prowadzą do relewantnej i zamierzonej interpretacji. Biorąc pod uwagę to, iż dużą część wiedzy o świecie zdobywa się $\mathrm{w}$ trakcie indywidualnych interakcji $\mathrm{z}$ otoczeniem, można spodziewać się, iż w przypadku osób niewidomych omówione powyżej luki w wiedzy mogą mieć negatywny wpływ na zrozumienie treści zależnej od posiadanej wiedzy zdobywanej przez interakcje wizualne - a takich jest większość. Warto też przywołać tu inny wątek omawiany w poprzedniej części artykułu, a mianowicie, iż w populacji osób niewidomych dostępność wiedzy powiązanej z doświadczeniem wizualnym będzie wysoce zależna od indywidualnej sytuacji danej osoby, tj. jakie otrzymała wsparcie edukacyjne w zakresie ogólnorozwojowym, w jakich zdarzeniach uczestniczyła itp. W nawiązaniu do przykładu ze stacją benzynową można przyjąć, że większość osób widzących wie, że stacje benzynowe sprzedają jedzenie (np. z treści reklam umieszczonych przy stacjach), nie powinno się natomiast automatycznie przyjmować takiego samego założenia w przypadku osób niewidomych.

Odnieśmy teraz powyższe rozważania dotyczące kompetencji pragmatycznej do przykładu testu z języka angielskiego umieszczonego w arkuszu maturalnym z maja 2017 r., poziom podstawowy. Odniesienie pojęcia kompetencji pragmatycznej do zrozumienia komunikatu w procesie nauczania języka obcego jest uzasadnione 
wnioskami z badań19, w których wykazano, iż kompetencja ta ma charakter uniwersalny, odgrywając taką samą rolę zarówno w interpretacji wypowiedzi w języku rodzimym, jak i w języku obcym. Poniższe omówienie tekstu ma na celu wykazanie, iż jego właściwe zrozumienie umożliwiające prawidłowe wykonanie zadania wymaga, jak w każdym przypadku, kompetencji pragmatycznej, która tutaj związana jest z wykorzystaniem odniesień do elementów wiedzy o charakterze wizualnym. Należy podkreślić, że test ten nie jest wyjątkowy pod względem wykorzystywania elementów wizualnych jako tła interpretacji ${ }^{20}$. Testów o podobnym charakterze jest wiele $\mathrm{w}$ arkuszach egzaminacyjnych, a ten konkretny został wybrany do analizy, ponieważ został użyty w arkuszu z niedawnej matury:

Egzamin maturalny poziom podstawowy, 8 maja 2017.

Przeczytaj tekst, z którego usunięto trzy zdania. Wpisz w luki 7.1.-7.3. litery, którymi oznaczono brakujące zdania (A-E), tak aby otrzymać logiczny i spójny tekst.

Uwaga: dwa zdania zostały podane dodatkowo i nie pasują do żadnej luki.

\section{A CLEVER IDEA}

One night four lazy college students were partying till midnight and didn't study for the test which was scheduled for the next day. In the morning, they thought of a perfect plan. 7.1. They told him they had gone out to their friend's wedding the previous night and during their return journey one tyre of their car had burst and they had to push the car all the way back. That was why it was impossible for them to write the test that day. They looked really exhausted.

The professor thought for a while and allowed them to return and take the test after three days.

${ }^{19} \mathrm{M}$. Jodłowiec, The role of relevance theory in SLA studies, [w:] Cognitive Processing in Second Language Acquisition, red. M. Putz, L. Sicola, John Benjamins, Amsterdam 2010, s. 49-66; E. Ifantidou, Pragmatic competence and explicit instruction, "Journal of Pragmatics" 2013, nr 59, s. 93-116.

20 A. Piskorska, Blind Learners and Comprehension Tasks, [w:] Contemporary English Language Teaching and Research, red. M. Marczak, M. Hinton, Cambridge Scholars Publishing, Newcastle upon Tyne 2015, s. 158-174. 
7.2 . They immediately went home to study. On the third day they came again to write the test. The professor explained that all four of them would have to sit in separate classrooms.

They weren't worried because they had worked hard for the previous three days to prepare.

7.3. They could get a maximum score of one hundred points as usual, but there were only two questions. The first one, for which they could get two points, was: What's your name? The second one, worth ninety-eight points, read: Which tyre burst?

adapted from www.quora.com

A. However, the test turned out to be different from what they had expected.

B. Unfortunately, they forgot to meet him on that day.

C. They made themselves look dirty and went to see their professor.

D. That was why he gave them more time to prepare.

E. They promised they would be ready by that time.

W tym krótkim tekście pojawia się kilka fragmentów, w tym jedna z możliwości uzupełnienia luki, których zrozumienie jest ściśle powiązane wiedzą o tym, jak wyglądają lub co widzą ludzie w określonych sytuacjach. Bohaterowie historyjki, którzy bawili się zamiast przygotowywać się do egzaminu, postanowili oszukać swojego profesora. W tym celu „sprawili, że wyglądali na brudnych" (dosłowne tłumaczenie angielskiego tekstu), przyszli do niego i opowiedzieli historyjkę, według której poprzedniego byli dnia na ślubie kolegi, a kiedy wracali, pękła im opona $\mathrm{w}$ samochodzie. Musieli więc pchać samochód z powrotem do kolegi, przez co nie mogli przygotować się do egzaminu. W tym miejscu pojawia się kolejna informacja wizualna - „wyglądali na naprawdę zmęczonych". Profesor zgodził się przełożyć test na inny dzień, po czym posadził każdego z kolegów w innej sali i w ramach egzaminu zadał pytanie „Która opona pękła?”.

Zrozumienie tego tekstu wymaga kilku stopni wnioskowania na podstawie informacji o charakterze wizualnym. Po pierwsze, należy wiedzieć (jest to jedna z luk), iż pobrudzenie się miało uwiarygodniać kłamstwo o pchaniu samochodu. Wydaje się to być przykła- 
dem takiego rodzaju wiedzy, która jest łatwo dostępna osobom widzącym (np. z filmów), w przypadku zaś osób niewidomych trudno jest ocenić, czy dana osoba taką wiedzę miała okazję zdobyć czy też nie. Po drugie, fragment mówiący, iż koledzy wyglądali na zmęczonych, należy zinterpretować, że naprawdę wyglądali tak po imprezie, natomiast przez profesora miało to być odebrane jako zmęczenie po pchaniu samochodu. Fragment ten może wprowadzić dość istotne wątpliwości interpretacyjne dla osoby niewidomej, ponieważ słowo „really" umacnia przekonanie, że zmęczenie było prawdziwe i niejako podważa wprowadzoną wcześniej linię rozumowania, iż cały akt był przez bohaterów udawany. Kluczem do zrozumienia tego fragmentu jest bowiem przesłanka o charakterze wizualnym, mówiąca, iż osoba bawiąca się całą noc, może wyglądać na zmęczoną tak samo, jak osoba, która wykonała ciężką pracę fizyczną. Kolejny element zrozumienia tekstu również zależy od doświadczenia opartego na wykorzystaniu zmysłu wzroku, mianowicie, osoby egzaminowane siedzące $w$ tej samej sali mogą sobie przekazać znaki, które pozwoliłyby zamaskować oszustwo. Również interpretacja "pytania egzaminacyjnego" jako czynnika mającego dowieść, iż profesor nie uwierzył w zmyśloną historię, zależy w kluczowy sposób od informacji wizualnej - dla osoby widzącej byłoby oczywiste, że każdy z uczestników takiego zdarzenia jak awaria opony w samochodzie wiedziałby, która opona uległa zniszczeniu, natomiast dla osoby niewidomej może to nie być oczywiste.

W świetle powyższej analizy pojawia się pytanie, jaki rodzaj umiejętności sprawdza $\mathrm{w}$ istocie rozwiązanie powyższego testu, jeśli przyjmujemy, iż kompetencja komunikacyjna obejmuje zarówno znajomość kodu językowego, jak i kompetencje pragmatyczną, wykorzystującą posiadaną wiedzę o świecie w procesie zrozumienia komunikatu poprzez wnioskowanie o intencjach mówiącego. Należy podkreślić, iż $\mathrm{w}$ analizowanym powyżej przykładzie testu z języka angielskiego wiedza oparta na bodźcach wizualnych wykorzystywana jest nie $\mathrm{w}$ celu odkodowania warstwy leksykalnej tekstu - byłoby tak, gdyby tekst zawierał np. nazwy kolorów czy też przymiotniki nazywające wizualne wrażenia estetyczne. Zro- 
zumienie takich słów zwykle nie stanowi szczególnego wyzwania dla uczniów niewidomych, którzy nie tylko znają definicje poszczególnych pojęć, ale często wypełniają ją własną, częściowo wyobrażoną treścią. W omawianym przykładzie odniesienia do wiedzy wizualnej mają miejsce na poziomie tła tekstu - przesłanek kontekstowych, które muszą być aktywowane, aby tekst mógł stanowić logiczną i spójną całość. Ponieważ nie są one jako takie obecne w samym tekście, uczniowi doświadczającego trudności z jego zrozumieniem trudno jest nawet wskazać, czego nie rozumie.

\section{Podsumowanie}

$\mathrm{W}$ artykule rozważono konsekwencje istnienia luk $\mathrm{w}$ wiedzy ogólnej występujących wśród osób niewidomych, wskazując, iż luki takie mogą znacznie obniżyć wyniki osiągane $\mathrm{w}$ testach rozumienia języka obcego. Dzieje się tak, ponieważ interpretacja niektórych tekstów w kluczowy sposób zależy od posiadania wiedzy kontekstowej uzyskanej poprzez przetwarzanie bodźców wizualnych, które osoba widząca napotyka bądź w bezpośrednim doświadczeniu, bądź w różnego rodzaju materiałach wizualnych.

Nie ulega wątpliwości, iż uczniowie niewidomi w drodze edukacji redukują wiele deficytów wiedzy powstałych na skutek braku takich bodźców. Jak podkreślono w niniejszym artykule, lekcje języka obcego również stanowią okazję do niwelowania różnic w obrazach świata. Nie ma również wątpliwości co do tego, że kompetencja pragmatyczna osób niewidomych, rozumiana jako zdolność wnioskowania o intencjach komunikacyjnych, może dorównywać kompetencji osób widzących. Wskazuje na to wiele przesłanek, takich jak podejmowanie przez osoby niewidome studiów na wydziałach filologicznych, oraz pracy $\mathrm{w}$ zawodzie tłumacza wymagającej przecież posiadania kompetencji pragmatycznej na bardzo wysokim poziomie.

Podejmując powyższe rozważania, pragniemy jedynie zwrócić uwagę, iż nie można przyjąć bezrefleksyjnie założenia, iż uczeń 
niewidomy w sytuacji zdawania egzaminu z języka obcego dysponuje odpowiednimi zasobami wiedzy i dodatkowo potrafi je wykorzystać, działając przecież w stresie. Należy pamiętać, że choć istnieje wiele sposobów kompensacji braku bezpośrednich interakcji wizualnych $\mathrm{z}$ otoczeniem, to nie można przyjmować, iż wszyscy uczniowie niewidomi $\mathrm{w}$ takim samym stopniu mieli okazję $\mathrm{z}$ nich skorzystać. Oprócz wspomnianych powyżej różnych rodzajów wsparcia rozwoju, jakie uczniowie mogli otrzymać, istotne są także czynniki losowe, takie jak znalezienie się w sytuacji, która stworzyła okazję do rozmowy na dany temat. Posiadanie określonej wiedzy kontekstowej zależy więc u osób $\mathrm{z}$ niepełnosprawnością wzroku w dużo większym stopniu od czynników indywidualnych, niż ma to miejsce w przypadku osób widzących.

Choć celem tego artykułu jest wskazanie i omówienie problemu, a nie proponowanie konkretnych rozwiązań dla praktyki edukacyjnej, w ramach wskazania możliwych kierunków działań stwierdzamy, iż w sytuacjach rozwiązywania testów opartych w dużej mierze na informacjach wizualnych uzasadnione jest dołączenie dodatkowych wyjaśnień dla uczniów niewidomych. Rozwiązanie takie pozwoliłoby wyrównać szanse i zapewnić wszystkim uczniom jednakowe możliwości rozwiązania testów.

\section{Bibliografia}

Cozendey S., da Piedade Costa M., The audio description as a physics teaching tool, "Journal of Research in Special Educational Needs" 2016, Vol. 16(1).

Czerwińska K., Pomoce dydaktyczne jako istotny element w edukacji uczniów z dysfunkcja wzroku, „Człowiek - Niepełnosprawność - Społeczeństwo”, 2013, nr 4(22).

Dłuska J., Karwowska M., Karasińska W. (red.), Świat w zasięgu ręki. Dobre praktyki w edukacji uczniów z dysfunkcja wzroku - projekt "Bliżej świata - od konkretu do abstrakcji", SOSW nr 1 dla Dzieci i Młodzieży Słabo Widzącej i Niewidomej, Bydgoszcz 2011.

Grice H.P., Logic and conversation, [w:] Studies in the way of words, red. H.P Grice, Harvard University Press, Cambridge, MA, 1975/89.

Ifantidou E., Pragmatic competence and explicit instruction, "Journal of Pragmatics", 2013, nr 59. 
Jakobson R., Poetyka w świetle językoznawstwa, przeł. K. Pomorska, „Pamiętnik Literacki: czasopismo kwartalne poświęcone historii i krytyce literatury polskiej", 1960, nr 51/2, s. 431-473. http:/ / bazhum.muzhp.pl/ [dostęp: 10.11.2015].

Jaworska-Biskup K., Dlaczego warto uczyć dzieci niewidome języków obcych? Język obcy jako kompensacyjne narzędzie w procesie poznawania świata $i$ zdobywania wiedzy na temat pojęć, [w:] Wyzwania wspótczesnej pedagogiki specjalnej - praktyka edukacyjna i rewalidacyjna, red. T. Żółkowska, B. Ostapiuk, M. Wlazło, Wydawnictwo Uniwersytetu Szczecińskiego, Szczecin 2010.

Jaworska-Biskup K., Wptyw rozumienia pojęć przez dzieci niewidome na nauczanie języków obcych, „Szkoła Specjalna” 2009, nr 1(248).

Jodłowiec M., The role of relevance theory in SLA studies, [w:] Cognitive Processing in Second Language Acquisition, red. M. Putz, L. Sicola, John Benjamins, Amsterdam 2010.

Konarska J., Aktywność komunikacyjna dzieci niewidomych jako warunek ich prawidłowego rozwoju i zapobieganie dystansowi spotecznemu, [w:] Dystans społeczny wobec osób z niepetnosprawnościa jako problem pedagogiki specjalnej. Tom I. Przyczyny - Konsekwencje - Przeciwdziatanie, red. M. Parchomiuk, B. Szabała, Wydawnictwo Uniwersytetu Marii Curie-Skłodowskiej, Lublin 2012.

Marek B., A blind child in an English classroom. "Network" 1999, nr 2/1.

Marzec A., Multiple Intelligences in Second Language Learning: Evidence from Sighted and Totally Blind Students. Rozprawa doktorska, KUL Jana Pawła II, Lublin 2017.

Mikołajczak-Matyja N., Wiedza o obiektach i zjawiskach naturalnych $w$ definicjach konstruowanych przez niewidomych i widzących użytkowników języka, „Szkoła Specjalna" 2006, nr 2.

Olczak A., Jezyk obcy w kształceniu zintegrowanym, [w:] Dziedziny kształcenia w klasach I-III, red. M. Magda-Adamowicz, L. Kataryńczuk-Mania, Wydawnictwo Akademickie Żak, Warszawa 2013.

Papadopoulos K., Metsiou K., Agaliotis I., Adaptive behavior of children and adolescents with visual impairments, "Research in Developmental Disabilities", nr 32.

Papuda-Dolińska B., Dziecko z niepetnosprawnościq wzroku w roli ucznia szkoty ogólnodostępnej, integracyjnej i specjalnej, Wydawnictwo Uniwersytetu Marii CurieSkłodowskiej, Lublin 2017.

Piskorska A., Blind Learners and Comprehension Tasks, [w:] Contemporary English Language Teaching and Research, red. M. Marczak, M. Hinton, Cambridge Scholars Publishing, Newcastle upon Tyne 2015.

Piskorska A., Krzeszowski T., Marek B., Uczeń z dysfunkcją wzroku na lekcji angielskiego. Wskazówki metodyczne dla nauczycieli, Uniwersytet Warszawski, Warszawa 2008.

Sak-Wernicka J., The guru effect in blind people's comprehension, [w:] Applications of Relevance Theory: From Discourse to Morphemes, red. A. Piskorska, E. Wałaszewska, Cambridge Scholars Publishing, Newcastle upon Tyne 2017. 
Sperber D., Wilson D., Relevance: Communication and Cognition. Blackwell, Oxford, 1986/95.

Śmiechowska-Petrovskij E., Komunikacja niewerbalna w relacji niewidomy-widzacy, [w:] Wspótcześni ludzie wobec wyzwań i zagrożeń XXI wieku, red. H. Liberska, A. Malina, D. Suwalska-Barancewicz, Difin, Warszawa 2014.

Walthes R., Einführung in die Blinden- und Sehbehindertenpädagogik, Reinhardt Verlag, München 2005.

Więckowska E., Edukacja nie wystarczy - potrzeby rewalidacyjne dziecka niewidomego w wieku szkolnym, [w:] Uwarunkowania i kierunki rozwoju pedagogiki specjalnej, red. B. Antoszewska, Cz. Kosakowski, Wydawnictwo Adam Marszałek, Torun 2011. Wilson D., Sperber D., Relevance theory, [w:] Handbook of Pragmatics, red. G. Ward, L. Horn, Oxford University Press, Oxford 2016. 